\title{
PERAN GURU DALAM IMPLEMENTASI KURIKULUM 2013 PENDIDIKAN KHUSUS PADA SEKOLAH LUAR BIASA DI SIDOARJO
}

\author{
Febrita Ardianingsih \\ Pendidikan Luar Biasa, Fakultas Ilmu Pendidikan, Universitas Negeri Surabaya \\ E-mail: febritaardianingsih@unesa.ac.id \\ Siti Mahmudah \\ Pendidikan Luar Biasa, Fakultas Ilmu Pendidikan, Universitas Negeri Surabaya \\ E-mail: mahmudah_plb@yahoo.com

\section{Edy Rianto} \\ Pendidikan Luar Biasa, Fakultas Ilmu Pendidikan, Universitas Negeri Surabaya \\ E-mail: edy.rianto@gmail.com
}

\begin{abstract}
Abstrak
Guru adalah pelaksana langsung dari kurikulum di suatu kelas. Pencapaian implementasi kurikulum yang baik sangat bergantung pada faktor kemampuan yang dimiliki oleh seorang guru. Beberapa Sekolah Luar Biasa di Sidoarjo telah mengimplementasikan Kurikulum 2013 Pendidikan Khusus. Oleh karena itu, dilakukan penelitian tentang "Peran Guru dalam Implementasi Kurikulum 2013 Pendidikan Khusus pada Sekolah Luar Biasa di Sidoarjo". Penelitian ini menggunakan pendekatan kualitatif dengan jenis penelitian deskriptif. Responden dalam penelitian ini adalah Kepala sekolah, Wali Kelas 1, dan Wali Kelas 4 di SLB Harmoni dan SLB Siti Hajar di kota Sidoarjo. Teknik pengumpulan data melalui observasi, wawancara dan dokumentasi. Keabsahan data dilakukan secara triangulasi teknik. Teknik analisis data bersifat induktif. Hasil penelitian ini adalah: (1) Implementasi Kurikulum 2013 Pendidikan Khusus pada Sekolah Luar Biasa di Sidoarjo dilaksanakan secara bertahap. Implementasi pembelajaran di kelas menggunakan perpaduan antara Kurikulum 2013 Pendidikan khusus dan Kurikulum KTSP; (2) Sebagian guru Sekolah Luar Biasa di Sidoarjo sudah menjalankan perannya sebagai perancang pembelajaran, pengajar, pembimbing, adaptor, dan evaluator sesuai kurikulum 2013 Pendidikan Khusus dengan beberapa adaptasi dari kurikulum KTSP; dan (3) Kendala yang dihadapi dalam Implementasi Kurikulum 2013 Pendidikan Khusus pada Sekolah Luar Biasa di Sidoarjo, antara lain: kurang lengkapnya ketersedian buku guru dan buku siswa, prasarana juga masih banyak yang perlu dibenahi, kurang lengkapnya alat peraga pendidikan, kurangnya pemahaman guru tentang penyusunan perangkat pembelajaran berdasarkan kurikulum 2013, dan kurangnya koordinasi dengan orang tua siswa.
\end{abstract}

Kata Kunci: Peran guru, Kurikulum 2013 Pendidikan Khusus, Sekolah Luar Biasa.

\begin{abstract}
Teacher is an implementator of Curriculum in a class. Good achievement of curriculum's implementation depends on the teacher's capability. Some Special Schools in Sidoarjo have already implemented Kurikulum 2013 Pendidikan Khusus. Therefore, this research performed "The Role of Special Teachers in Implementation of Kurikulum 2013 Pendidikan Khusus at Special School in Sidoarjo". The research was qualitative descriptive study. The respondents were principal, grade 1 teacher, and grade 4 teacher from SLB Siti Hajar and SLB Harmoni in Sidoarjo. The Techniques of collecting data were observation, interview and documentation. The data validity use triangulation. Data analysis was inductive. Results are: (1) Kurikulum 2013 Pendidikan Khusus at special school in Sidoarjo is implemented gradually. Implementation of the curriculum in the classroom at special school is an assimilation between Kurikulum 2013 Pendidikan Khusus and Kurikulum KTSP; (2) Some special teachers in Sidoarjo are already running their role as planner, instructor, mentor, adapter, and evaluator corresponding to Kurikulum 2013 Pendidikan Khusus with some adaptations from Kurikulum KTSP; and (3) The obstacle in implementation of Kurikulum 2013 Pendidikan Khusus at Special School in Sidoarjo, including: the lack of Teacher's books and student's books, infrastructure, learning tools, teacher's understanding on learning tools based on Kurikulum 2013 Pendidikan Khusus, and coordination with parents.
\end{abstract}

Keywords: The Role of Special Teachers, Kurikulum 2013 Pendidikan Khusus, Special School. 


\section{PENDAHULUAN}

Kurikulum adalah hal yang penting dalam terlaksananya pendidikan. Kurikulum di Indonesia menjadi salah satu acuan yang digunakan oleh sekolahsekolah agar pendidikan dapat berjalan dengan baik, efektif dan efisien sesuai yang diharapkan. Karena hal tersebut, maka pemerintah selalu berusaha mengembangkan kurikulum pendidikan yang telah ada menjadi lebih baik lagi.

Kurikulum di Indonesia telah mengalami beberapa kali perubahan, yaitu pada tahun 1947, 1952, 1964, 1968, 1975, 1984, 1994, 2004, 2006, dan tahun 2013. Perubahan tersebut merupakan konsekuensi logis dari terjadinya perubahan sistem politik, sosial, budaya, ekonomi, dan iptek dalam masyarakat berbangsa dan bernegara. Sebab, kurikulum sebagai seperangkat rencana pendidikan perlu dikembangkan secara dinamis sesuai dengan tuntutan dan perubahan yang terjadi di masyarakat.

Pada tahun 2013 pemerintah Indonesia telah berhasil melakukan pembaharuan kurikulum persekolahan yang selanjutnya dikenal dengan sebutan Kurikulum 2013. Pada tahun pelajaran 2013/2014 kurikulum tersebut telah dilaksanakan secara terbatas di sejumah sekolah reguler di berbagai wilayah di Indonesia. Selanjutnya, pada tahun 2014 pemerintah berupaya untuk mengembangkan kurikulum untuk anak berkebutuhan khusus, yang dinamakan dengan Kurikulum 2013 Pendidikan Khusus. Kurikulum 2013 Pendidikan Khusus telah dilaksanakan secara terbatas di sejumlah sekolah luar biasa bagi perserta didik kelas 1, 4 dan 7 pada tahun 2014 dan ditambah kelas 2, 5, dan 8 pada tahun 2015 .

Penerapan Kurikulum 2013 dilakukan melalui pembelajaran dengan pendekatan tematik terpadu. Pembelajaran tematik terpadu merupakan pendekatan pembelajaran yang mengintegrasikan berbagai kompetensi dari berbagai mata pelajaran ke dalam berbagai tema. Pembelajaran berbasis tematik integratif yang diterapkan pada sekolah-sekolah ini menyuguhkan proses belajar berdasarkan tema untuk kemudian dikombinasikan dengan mata pelajaran lainnya. Kurikulum 2013 disiapkan untuk mencetak generasi yang siap didalam menghadapi masa depan. Karena itu kurikulum disusun untuk mengantisipasi perkembangan masa depan. Titik beratnya, bertujuan untuk mendorong peserta didik agar memiliki pengalaman belajar dalam 5 M yakni mengamati, menanya, mencari informasi, mengasosiasi, dan mengomunikasikan apa yang mereka peroleh atau mereka ketahui setelah menerima materi. Kurikulum 2013 merupakan kurikulum yang dibuat untuk pembentukan kompetensi dan karakter peserta didik untuk menghasilkan peserta didik yang produktif, kreatif, inovatif, afektif melalui penguatan sikap, keterampilan dan pengetahuan yang terintegrasi dengan kurikulum yang disesuaikan dengan peserta didik.

Sekolah luar biasa diberikan keleluasaan untuk mengembangkan Kurikulum 2013 Pendidikan Khusus sesuai dengan kondisi satuan pendidikan, kebutuhan peserta didik, dan potensi daerah. Oleh sebab itu, sebagai seorang guru di Sekolah Luar Biasa dituntut untuk mengimplementasikan Kurikulum 2013 Pendidikan Khusus agar dapat meningkatkan persaingan yang sehat antar-satuan pendidikan tentang kualitas pendidikan yang akan dicapai. Implementasi Kurikulum 2013 Pendidikan Khusus, dapat tercapai dengan baik, sangat bergantung pada faktor kemampuan yang dimiliki oleh seorang guru. Artinya, guru adalah orang yang bertanggung jawab dalam upaya mewujudkan segala sesuatu yang telah tertuang dalam suatu kurikulum resmi yaitu Kurikulum 2013 Pendidikan Khusus. Bagaimanapun idealnya kurikulum tanpa ditunjang oleh kemampuan guru untuk mengaktualisasikan dan mengimplementasikannya, maka kurikulum tidak akan bermakna sama sekali dan pembelajaran tidak akan efektif (Alawiyah, 2013).

Guru menjadi garda terdepan dalam penyelenggaraan pendidikan di Indonesia. Keberhasilan pendidikan ada di tangan guru. Guru adalah individu yang berhadapan langsung dengan peserta didik di kelas dalam pembelajaran. guru memiliki peran penting untuk membuat peserta didik berkualitas baik akademis, keahlian, kematangan emosional, moral serta spiritual. Untuk menunjang semua itu, diperlukan sosok guru yang memiliki kualifikasi, kompetensi, serta dedikasi yang tinggi dalam menyelenggarakan tugasnya. Peran guru dalam pembelajaran antara lain yaitu guru sebagai perancang pembelajaran, guru sebagai pengajar, guru sebagai pembimbing, dan guru sebagai evaluator (Mulyasa, 2008). Tugas dan tanggung jawab guru adalah guru mampu menjabarkan, merumuskan dan menguasai bahan dan tujuan pembelajaran yang akan diajarkan kepada peserta didik, serta guru harus memiliki cara berfikir positif terhadap profesi yang diembannya. Selain itu guru harus kreatif dan terampil dalam memberikan pengajaran dan memahami karakteritik peserta didik agar tujuan pendidikan lebih mudah tercapai. Dengan demikian, guru akan memberikan kemudahan belajar bagi seluruh peserta didik agar dapat mengembangkan potensinya secara optimal.

Di Sidoarjo terdapat beberapa Sekolah Luar Biasa yang telah mengimplementasikan Kurikulum 2013 Pendidikan Khusus. Namun, masih minim informasi mengenai bagaimana implementasi Kurikulum 2013 Pendidikan Khusus, peran guru, dan kendala yang dihadapi guru pada Sekolah Luar Biasa di Sidoarjo. Oleh karena itu, penting dilakukan penelitian yang bertujuan untuk mengetahui gambaran detail mengenai peran guru dalam implementasi Kurikulum 2013 Pendidikan Khusus Pada Sekolah Luar Biasa di Sidoarjo, dengan rincian sebagai berikut. Pertama, mendeskripsikan implementasi kurikulum 2013 pendidikan khusus pada Sekolah Luar Biasa di Sidoarjo. Kedua, mendeskripsikan peran guru dalam implementasi kurikulum 2013 pendidikan khusus pada Sekolah Luar Biasa di Sidoarjo. Ketiga, mendeskripsikan kendala yang dihadapi guru dalam implementasi kurikulum 2013 pendidikan khusus pada Sekolah Luar Biasa di Sidoarjo 


\section{METODE}

Jenis penelitian yang digunakan dalam penelitian ini adalah deskriptif. Data yang akan dideskripsikan dalam penelitian ini adalah data mengenai implementasi kurikulum 2013 pendidikan khusus pada Sekolah Luar Biasa di Sidoarjo, peran guru dalam implementasi Kurikulum 2013 Pendidikan Khusus pada Sekolah Luar Biasa di Sidoarjo, dan kendala yang dihadapi guru dalam implementasi Kurikulum 2013 Pendidikan Khusus pada Sekolah Luar Biasa di Sidoarjo. Lokasi penelitian adalah dua Sekolah Luar Biasa di Sidoarjo yang telah mengimplementasikan Kurikulum 2013 Pendidikan Khusus, yaitu SLB Harmoni dan SLB Siti Hajar. Responden yang terlibat adalah kepala sekolah, wali kelas 1, dan wali kelas 4 dari SLB Harmoni dan SLB Siti Hajar di Sidoarjo. Teknik pengumpulan data berupa: (1) Observasi; Observasi dilakukan untuk mendapatkan data peran guru dalam implementasi Kurikulum 2013 Pendidikan Khusus pada Sekolah Luar Biasa, (2) Wawancara; Wawancara dilakukan terhadap guru dan kepala sekolah, (3) Dokumentasi; Dokumentasi yang dilakukan dalam penelitian ini adalah untuk mengumpulkan data penunjang, yaitu: program tahunan, program semester, silabus, Rencana Pelaksanaan Pembelajaran, Program Pembelajaran Individual, Buku guru, Buku siswa, data kepala sekolah, data guru, data siswa, Lembar penilaian, lembar Kerja Siswa, Program Layanan Khusus ABK, dan Catatan Perkembangan Peserta Didik. Instrumen yang digunakan dalam penelitian ini merupakan instrumen yang dikembangkan sendiri oleh tim peneliti dengan melalui tahapan validasi dari pakar.

Teknik analisis data melalui tiga proses, yaitu: (1) reduksi data; data yang telah terkumpul dari hasil wawancara, observasi, maupun dokumentasi diringkas untuk mempertegas, memperpendek, membuat fokus, membuang hal-hal yang tidak diperlukan, dan mengatur data sedemikian rupa sehingga simpulan penelitian dapat dilakukan, (2) sajian data; dalam bentuk kalimat-kalimat yang mendeskripsikan hasil yang diperoleh di lapangan, dan (3) penarikan simpulan; simpulan akhir dilakukan setelah data terkumpul semua, namun simpulan ini masih perlu dilakukan verifikasi supaya dapat dipertanggungjawabkan. Pengujian keabsahan data dengan menggunakan triangulasi teknik, yaitu dari observasi, wawancara, dan dokumentasi.

\section{HASIL DAN PEMBAHASAN}

\section{Implementasi kurikulum 2013 pendidikan khusus} pada Sekolah Luar Biasa di Sidoarjo

Kurikulum merupakan salah satu komponen yang sangat penting dalam penyelenggaraan pendidikan. Kurikulum digunakan sebagai acuan dalam penyelenggaraan pendidikan dan merupakan salah satu indikator mutu pendidikan. Hamalik dalam Suyadi \& Dahlia (2014) menjelaskan bahwa kurikulum adalah perencanaan kesempatan belajar untuk membina siswa kearah perubahan perilaku yang dinginkan dan menilai hingga dimana perubahan- perubahan tersebut telah terjadi pada diri siswa yang bersangkutan. Dalam dunia Pendidikan, kehadiran kurikulum dianggap penting, karena telah dirasakan oleh pengelola pendidikan akan fungsi dan peranannya yang strategis. Kurikulum bersifat luas, karena kurikulum bukan hanya terdiri dari atas mata pelajaran tetapi juga meliputi semua kegiatan dan pengalaman yang menjadi tanggung jawab sekolah. Pelaksanaan kurikulum tidak hanya di dalam kelas tetapi di luar kelas sesuai dengan tujuan yang hendak dicapai. Dalam pencapaian hasil belajar dalam Pendidikan Luar Biasa (PLB) kurikulum yang berlaku mengalami penyesuaian untuk setiap kebutuhan anak. Kurikulum 2013 Pendidikan Khusus menggunakan filosofi sebagaimana dalam mengembangkan kehidupan individu peserta didik berkebutuhan khusus dalam beragama, seni, kreatifitas, berkomunikasi, nilai dan berbagi dimensi inteligensi yang sesuai dengan diri seorang peserta didik dan diperlukan masyarakat, bangsa dan umat manusia (Kemendikbud, 2015:16).

Implementasi kurikulum 2013 dilakukan dengan bertahap diawali dengan mengimplementasikan kurikulum 2013 pada pendidikan umum atau reguler kemudian dilanjutkan pada pengimplementasian kurikulum 2013 pada Pendidikan Khusus. Sekolah Luar Biasa mulai menerapkan kurikulum 2013 sebagai salah satu pedoman kurikulum sekolah pada awal tahun pelajaran 2015-2016.

Penelitian ini menguatkan pernyataan diatas, yaitu beberapa Sekolah Luar Biasa di Kabupaten Sidoarjo juga mulai mengimplementasikan Kurikulum 2013 Pendidikan Khusus pada tahun pelajaran baru 2015/ 2016, namun belum semua jenjang kelas di SLB menerapkan kurikulum 2013 Pendidikan Khusus ini sebagai pedoman kurikulum pembelajaran. Hanya beberapa kelas saja yang sudah mengimplementasikannya, diantaranya kelas 1 dan kelas 4 SDLB. Sedangkan pada tahun ajaran 2016/2017 ditambah kelas 2 dan kelas 5. Pengimplementasian bertahap tersebut sejalan dengan pendapat Kementrian Pendidikan dan Kebudayaan RI mengenai panduan teknis pengembangan kurikulum 2013 Pendidikan Khusus (2015:19) yang menjelaskan bahwa: "Pengembangan dan penyiapan kurikulum pendidikan khusus 2013 dilakukan secara bertahap. Diawali dengan pengembangan dan penyiapan kurikulum untuk pendidikan dasar dan menengah pada kurun waktu 2013-2015. Setahun kemudian, bertahap kepada pengembangan dan penyiapan kurikulum pendidikan khusus (termasuk penataan sistem pembelajarannya) pada kurun waktu 2013-2016.

Kurikulum 2013 sempat menemui beberapa kendala dalam pelaksanaannya, antara lain mengenai ketidakselarasan antara ide dengan desain kurikulum hingga mengenai ketidakselarasan gagasan dengan isi buku teks. Karena hal tersebut, sampai tahun 2015 
kurikulum 2013 tidak diterapkan di semua sekolah di Indonesia. Terbukti dari temuan penelitian ini bahwa implementasi Kurikulum 2013 Pendidikan Khusus pada SLB di Sidoarjo belum bisa dikatakan sempurna dan masih ada beberapa kendala, yang akan dijelaskan lebih detail pada poin 3. Sehingga dampak dari adanya kendala pengimplementasian Kurikulum 2013 Pendidikan Khusus adalah ada beberapa konsep dari kurikulum sebelumnya yaitu kurikulum tingkat satuan pendidikan (KTSP) yang masih digunakan. Dalam upaya mengimplementasikan kurikulum 2013 Pendidikan Khusus, pihak Sekolah Luar Biasa di Sidoarjo mencoba mengatasinya dengan turut berpartisipasi dalam kegiatan pelatihan- pelatihan tentang kurikulum 2013 yang diselenggarakan oleh pemerintah.

2. Peran guru dalam implementasi Kurikulum 2013 Pendidikan Khusus pada Sekolah Luar Biasa di Sidoarjo

Guru merupakan figur utama dalam pelaksanaaan pembelajaran. keberhasilan suatu kurikulum yang diterapkan pada pembelajaran tidak terlepas dari peran seorang guru didalamnya. Dalam mengimplementasikan kurikulum di kegiatan pembelajaran, guru harus memahami dan menguasai isi yang tertuang dalam kurikulum tersebut, untuk itu guru harus mempersiapkan diri terhadap perubahan kurikulum pembelajaran.

Data dari hasil wawancara, observasi dan dokumentasi dalam penelitian ini, secara umum dapat menunjukkan bahwa peran guru dalam implementasi kurikulum 2013 pada Sekolah Luar Biasa di Sidoarjo sudah baik. Guru sudah membuat perencanaan pembelajaran seperti program tahunan, program semester, rincian minggu efektif, silabus, dan Rencana Pembelajaran (RPP). Silabus merupakan rencana pembelajaran pada suatu mata pelajaran atau tema tertentu yang mencakup kompetensi inti, kompetensi dasar, materi pembelajaran, kegiatan pembelajaran, penilaian, alokasi waktu, dan sumber belajar. Secara umum, pengembangan silabus Kurikulum 2013 Pendidikan Khusus sama seperti pengembangan silabus pada kurikulum-kurikulum sebelumnya. RPP merupakan suatu bentuk perencanaan pembelajaran yang akan dilaksanakan oleh pendidik dalam kegiatan belajar mengajar. Program tahunan dan program semester merupakan salah satu komponen dalam perangkat pembelajaran. Program tahunan perlu dipersiapkan dan dikembangkan oleh guru sebelum tahun pelajaran, karena merupakan pedoman bagi pengembangan program-program berikutnya, yakni program semester. Program semester atau promes merupakan rencana waktu yang akan dilaksanakan guru dalam satu semester.

Perencanan pembelajaran disusun setiap tahun ajaran baru kemudian diserahkan ke kepala sekolah. Program pembelajaran ini akan dievaluasi setiap semesternya oleh kepala sekolah, dan semua guru apakah di semester yang akan datang layak dilanjutkan ataukah harus membuat perencanaan ulang. Hal ini sejalan dengan teori Moon dalam Uno (2008: 22) yaitu, Guru sebagai perancang pembelajaran. Senada dengan pendapat Sanjaya (2008) bahwa guru berperan sebagai developers, yaitu memiliki peran dalam menentukan tujuan dan isi pelajaran yang akan disampaikan.

Disamping guru berperan sebagai perancang pembelajaran, guru juga berperan dalam mendidik anak- anak di dalam kelas. Guru membimbing siswa dalam belajar. Pembelajaran yang menerapkan kurikulum 2013 identik dengan pendekatan saintifik. Pendekatan saintifik merupakan ciri khas dalam implementasi kurikulum 2013. Pendekatan saintifik adalah pendekatan yang digunakan dalam pembelajaran tersebut dilakukan melalui proses ilmiah. Pelaksanaan kegiatan pembelajaran pada kurikulum 2013 menggunakan pendekatan saintifik, walaupun dalam prakteknya antara sekolah satu dengan lainnya tidak sama, tetapi konsep dasar yang digunakan sama yaitu mengamati, menanya, menyajikan, menyimpulkan, mengkomunikasikan. Penelitian ini berhasil memberikan gambaran bahwa guru Sekolah Luar Biasa di Kabupaten Sidoarjo sudah berupaya menerapkan pendekatan saintifik ini kepada anak berkebutuhan khusus meskipun dalam pelaksanaannya belum berjalan secara maksimal mengingat kemempuan anak yang terbatas. Peran guru Sekolah Luar Biasa di Sidoarjo dalam pembelajaran di kelas, seperti yang tersebut diatas, sesuai dengan pendapat yang dikemukakan Mulyasa (2008:37) bahwa "guru berperan sebagai pengajar sejak adanya kehidupan sejak saat itu pula guru telah melaksanakan pembelajaran, dan memang hal tersebut merupakan tugas dan tanggung jawabnya yang pertama dan utama. Guru membantu peserta didik yang sedang berkembang untuk mempelajari sesuatu yang belum diketahuinya, membentuk kompetensi dan memahami materi standar yang dipelajari. “

Selanjutnya dalam kegiatan pembelajaran, guru Sekolah Luar Biasa harus memiliki kesabaran karena karakter anak yang berbeda satu dan yang lainya. Pada dasarnya pendekatan yang dilakukan dalam berinteraksi dengan siswa bekebutuhan khusus memiliki trik yang sama yakni pendekatan secara individu, sabar, tulus dan ikhlas karena kondisi anak dengan berbagai karakter. Guru Sekolah Luar Biasa di Sidoarjo sudah menyusun Program Pembelajaran Individual. Program pembelajaran individual adalah suatu program pembelajaran yang disusun untuk membantu peserta didik berkebutuhan khusus sesuai dengan kemampuannya. Tindakan guru Sekolah Luar Biasa di Sidoarjo dalam menyusun Program Pembelajaran Individual sesuai dengan pendapat Sanjaya (2008) yang menyebutkan bahwa guru berperan sebagai adapters. Alawiyah (2013) menambahkan bahwa guru sebagai adapters memiliki kewenangan lebih 
untuk menyesuaikan kurikulum yang sudah ada dengan karakteristik sekolah, peserta didik, materi, maupun kebutuhan lokal.

Selain memiliki peran dalam pembelajaran, guru Sekolah Luar Biasa di Sidoarjo juga melakukan evaluasi terhadap hasil pembelajaran. Guru melakukan evaluasi di setiap akhir pembelajaran, dengan mengevaluasi dalam aspek sikap, pengetahuan, dan keterampilan siswa. Penilaian ini dilakukan secara berkala, mulai dari menilai proses kegiatan pembelajaran serta memberikan ulanganulangan dalam selama satu semester pembelajaran. Dalam hal ini sejalan dengan teori Moon dalam Uno (2008:25), bahwa guru sebagai evaluator "Tujuan utama penilaian adalah untuk melihat tingkat keberhasilan, efektivitas dan efisiensi dalam proses pembelajaran. Dalam fungsinya sebagai penilai hasil belajar peserta didik, guru hendaknya secara terus menerus mengikuti hasil belajar yang telah dicapai peserta didik dari waktu ke waktu." Peran guru sebagai evaluator senada dengan pendapat yang disampaikan oleh Sanjaya (2008) bahwa guru berperan sebagai developers, yaitu bukan hanya memiliki peran dalam menentukan tujuan dan isi pelajaran yang akan disampaikan, tetapi juga dapat menentukan strategi yang akan dikembangkan serta bagaimana mengukur keberhasilannya melalui pemilihan alat evaluasi untuk pencapaian hasil belajarnya.

Evaluasi merupakan suatu penilaian terhadap suatu kinerja yang sudah dikerjakan. Teknis atau cara yang digunakan dalam evaluasi untuk mengetahui keberhasilan dalam suatu pembelajaran. Kegiatan evaluasi dilakukan Selama kegiatan pembelajaran berlangsung dan setelah pembelajaran, selanjutnya guru mengevaluasi kegiatan pembelajaran tersebut baik proses maupun hasil. Evaluasi dalam kurikulum 2013 ini meliputi penilaian sikap, pengetahuan dan keterampilan. Aspek sikap di nilai pada saat kegiatan pembelajaran berlangsung yang meliputi sikap percaya diri, disiplin dan bekerja sama. Untuk aspek pengetahuan, menggunakan tes lisan dan tes tulis, selanjutnya dalam aspek penilaian keterampilan, melakukan penilaian terhadap siswanya melalui pengamatan atau observasi dan unjuk kerja selama kegiatan pembelajaran berlangsung. Penilaian tersebut sudah tertuang dalam Rencana Pelaksanaan Pembelajaran yang telah disusun oleh guru sebelumnya.

Selanjutnya pelaporan hasil evaluasi terhadap peserta didik dibukukan dalam bentuk raport. Dalam menyususn raport, sebagian guru Sekolah Luar Biasa di Sidoarjo ada yang sudah menggunakan raport kurikulum 2013, dan ada yang masih menggunakan raport KTSP. Dalam raport kurikulum 2013 yang disusun oleh guru, penilaian dirincikan setiap Kompetensi Inti, yang mencakup aspek spiritual (KI 1), aspek sosial (KI 2), pengetahuan (KI 3), dan keterampilan (KI 4). Penilaian dalam raport kurikulum 2013 diuraikan dalam bentuk deskripsi narasi dan disertai dengan capaian hasil belajar yang diklasifikasikan dalam predikat atau skala 1-4.

3. Kendala yang dihadapi dalam implementasi Kurikulum 2013 Pendidikan Khusus pada Sekolah Luar Biasa di Sidoarjo

Sekolah Luar Biasa berusaha meningkatkan kualitas pendidikannya dengan menerapkan Kurikulum 2013 Pendidikan Khusus sebagai salah satu pedoman kurikulum dalam pembelajaran. Penerapan kurikulum 2013 Pendidikan Khusus pada Sekolah Luar Biasa di Sidoarjo memang belum dikatakan sempurna.

Data dari hasil observasi, wawancara, dan dokumentasi menunjukkan bahwa terdapat kendala dalam implementasi Kurikulum 2013 Pendidikan Khusus pada Sekolah Luar Biasa di Sidoarjo. Kurang matangnya kesiapan Sekolah Luar Biasa dalam mengimplementasikan Kurikulum 2013 Pendidikan Khusus menyebabkan penerapan Kurikulum 2013 Pendidikan Khusus di Sekolah Luar Biasa di Sidoarjo kurang maksimal. Kurang lengkapnya ketersedian buku guru dan buku siswa menjadi salah satu kendala dalam menerapkan Kurikulum 2013 Pendidikan Khusus pada Sekolah Luar Biasa di Sidoarjo. Selain itu sarana prasarana Sekolah Luar Biasa di Sidoarjo juga masih banyak yang perlu dibenahi, misalnya kurang lengkapnya alat peraga pendidikan. Hal tersebut sesuai dengan pernyataan dalam Permendikbud No. 81a tahun 2013, yakni "sarana dan prasarana yang belum memadai, guru dan siswa yang belum siap dalam menerima dan melaksanakan pembelajaran menggunakan kurikulum baru." Juga diperkuat dengan pendapat Kristiantari (2014) bahwa walaupun motivasi guruguru dalam mengimplementasikan inovasi pembelajaran dalam Kurikulum 2013 sangat tinggi, namun hal tersebut kurang didukung oleh fasilitas, sarana dan prasarana

Selanjutnya kendala lain dalam implementasi Kurikulum 2013 Pendidikan Khusus pada Sekolah Luar Biasa di Sidoarjo yaitu kurangnya pemahaman guru tentang penyusunan perangkat pembelajaran berdasarkan Kurikulum 2013 Pendidikan Khusus. Belum semua guru Sekolah Luar Biasa di Sidoarjo menyusun perangkat berdasarkan Kurikulum 2013 Pendidikan Khusus, melainkan ada yang masih menyusun perangkat pembelajaran sesuai dengan kurikulum 2006. Belum adanya contoh resmi dalam penyusunan perangkat seperti silabus, prota dan promes berdasarkan Kurikulum 2013 Pendidikan Khusus menjadi salah satu alasan guru Sekolah Luar Biasa di Sidoarjo belum menyusun perangkat pembelajaran berdasarkan Kurikulum 2013 Pendidikan Khusus. Hal ini yang menjadikan tidak semua guru Sekolah Luar Biasa di Sidoarjo menerapkan Kurikulum 2013 Pendidikan Khusus dalam pembelajaran. Temuan ini 
selaras dengan Albantani (2015) bahwa pengembangan Kurikulum 2013 di sekolah tidak utuh, sehingga guru dan sekolah belum memahami secara penuh implementasi Kurikulum 2013.

Hambatan lainnya yang dihadapi oleh guru Sekolah Luar Biasa di Sidoarjo adalah kurangnya koordinasi dengan orang tua siswa karena dalam kurikulum 2013 Pendidikan Khusus menuntut adanya kerja sama antara guru dan orang tua demi keberhasilan kurikulum yang akan dicapai. Seperti yang disampaikan oleh Ningrumdan Sobri (2015) bahwa orang tua peserta didik dan juga peserta didik merupakan salah satu pendukung dalam implementasi Kurikulum 2013.

\section{PENUTUP}

\section{Simpulan}

Dari hasil penelitian tersebut dapat disimpulkan bahwa: (1) Implementasi Kurikulum 2013 Pendidikan Khusus pada Sekolah Luar Biasa di Sidoarjo dilaksanakan secara bertahap, dimulai sejak tahun ajaran 2015/2016 pada kelas 1 dan 4 dan pada tahun ajaran 2016/2017 ditambah kelas 2 dan kelas 5. Implementasi pembelajaran di kelas menggunakan perpaduan antara Kurikulum 2013 Pendidikan khusus dan Kurikulum KTSP; (2) Sebagian guru Sekolah Luar Biasa di Sidoarjo sudah menjalankan perannya sebagai perancang pembelajaran, pengajar, pembimbing, adaptor, dan evaluator sesuai kurikulum 2013 Pendidikan Khusus dengan beberapa adaptasi dari kurikulum KTSP, yaitu melakukan perencanaan pembelajaran seperti program tahunan, program semester, rincian minggu efektif, silabus, dan Rencana Pembelajaran (RPP), melaksanakan pembelajaran dengan pendekatan saintifik, dan mengadakan evaluasi yang meliputi aspek sikap, pengetahuan, dan keterampilan; (3) Kendala yang dihadapi dalam Implementasi Kurikulum 2013 Pendidikan Khusus pada Sekolah Khusus di Sidoarjo, antara lain: Kurang lengkapnya ketersedian buku guru dan buku siswa, prasarana juga masih banyak yang perlu dibenahi, kurang lengkapnya alat peraga pendidikan, kurangnya pemahaman guru tentang penyusunan perangkat pembelajaran berdasarkan kurikulum 2013, serta kurangnya koordinasi dengan orang tua siswa.

\section{Saran}

Ada beberapa hal yang dapat dilakukan untuk semakin meningkatkan peran guru dalam implementasi Kurikulum 2013 Pendidikan Khusus, antara lain: (1) Bagi pemangku kebijakan: rutin mengadakan pelatihan tentang implementasi Kurikulum 2013 Pendidikan Khusus dengan menyasar peserta yang belum pernah mendapat pelatihan sebelumnya dan menjamin ketersediaan buku guru dan buku siswa di sekolah khusus, (2) Bagi Kepala sekolah: memacu kreatifitas guru dalam menyediakan alat peraga pendidikan dan memberi kesempatan bagi guru yang pernah mengikuti pelatihan untuk menyebarluaskan pengetahuan yang telah didapat, serta memberi kesempatan kepada guru yang belum pernah mengikuti pelatihan dalam pelatihan berikutnya, (3) Bagi Guru: meningkatkan kreatifitas dalam menyediakan media belajar dan memacu diri untuk terus belajar dan menerima perubahan, serta meningkatkan koordinasi dengan orang tua siswa.

\section{DAFTAR PUSTAKA}

Abdullah. 2016. Kodipter sebagai Model Pendampingan Kurtilas untuk Meningkatkan Kualitas Pembelajaran Guru Kelas SMPLB pada SLB Binaan di Kota Surakarta Tahun Pelajaran 2015/2016. Jurnal Rehabilitasi dan Remediasi. Vol. 25. No.1. Hal. 6-12.

Alawiyah, F. 2013. Peran Guru dalam Kurikulum 2013. Ekspresi. Vol.4. No.1. Hal. 65-74.

Albantani, A.M. 2015. Implementasi Kurikulum 2013 pada Pembelajaran Bahasa Arab di Madrasah Ibtidaiyah. Jurnal Pendidikan Bahasa Arab dan Kebahasaaraban. Vol. 2. No. 2. Hal. 178-191.

Ardhana. 2008. Penelitian Deskriptif, (Online), http:/ardhana12.wordpress.com (diakses 11 Februari 2016).

Fadlillah, M. 2014. Implementasi Kurikulum 2013 dalam Pembelajaran SD/ MI, SMP/ MTS, \& SMA/ MA. Yogyakarta: Ar-Ruzz Media.

Kementrian Pendidikan dan kebudayaan Republik Indonesia. 2014. Pedoman Pelaksanaan Kurikulum bagi Peserta Didik Berkebutuhan Khusus di Sekolah Reguler. Jakarta: Kementrian Pendidikan dan kebudayaan Republik Indonesia.

Kristiantari, R. 2014. Analisis Kesiapn Guru Sekolah Dasar dalam Mengimplementasikan Pembelajaran Tematik Integratif Menyongsong Kurikulum 2013. Jurnal Pendidikan Indonesia. Vol.3. No.2. Hal. 460470

Mulyasa, E. 2014. Guru dalam Implementasi Kurikulum 2013. Bandung: PT Remaja Rosdakarya Offset.

Mulyasa, E. 2008. Menjadi Guru Profesional. Bandung: PT Remaja Rosdakarya Offset.

Nasution, S. 2003. Asas- asas kurikulum. Jakarta: Bumi aksara.

Ningrum, E.S. dan Sobri, A.Y. 2015. Implementasi Kurikulum 2013 di Sekolah Dasar. Manajemen Pendidikan. Vol. 24. No. 5. Hal. 416-423 
Peraturan Pemerintah Nomor 19 Tahun 2005 tentang Standar Kompetensi Lulusan.

Rohman, Muhammad dan Amri, Sofan. 2012. Manajemen Pendidikan Analisis dan solusi terhadap kinerja manajemen kelas dan strategi pengajaran yang efektif, Jakarta: Prestasi pustakarya.

Sanjaya, Wina. 2008. Kurikulum dan Pembelajaran. Bandung: Kencana prenada Media group.

Sugiyono. 2012. Metode Penelitian Kuantitatif Kualitatif dan $R \& D$. Bandung: Alfabeta.

Sutopo, H.B. 2002. Metodologi Penelitian Kualitatif. Surakarta: Sebelas Maret University Press.

Suyadi dan Dahlia. 2014. Implementasi dan Inovasi Kurikulum Paud 2013: Program Pembelajaran Berbasis Multiple Intelligences. Bandung: PT Remaja Rosdakarya Offset.

Undang-undang Republik Indonesia nomor 20 tahun 2003 tentang Sistem Pendidikan Nasional pasal 1 ayat 1 tantang pengertian pendidikan.

Undang-Undang Nomor 20 Tahun 2003 tentang Sistem Pendidikan Nasional dalam pasal 3 tentang tujuan pendidikan nasional.

Undang-Undang Nomor 20 tahun 2003 tentang Sistem Pendidikan Nasional tentang pengertian kurikulum.

Undang-undang Nomor 14 tahun 2005 tentang Guru dan Dosen tentang pengertian guru

Uno, Hamzah. B. Profesi Kependidikan. 2007. Jakarta. Bumi Aksara. 